\title{
COVID-19 and Gender Role in Unemployment: How Women in Special Capital Region of Jakarta is Less Likely to be Unemployed During Economic Disturbance
}

\author{
Jamal Habibur Rahman ${ }^{1}$, Faradisa Hilya Mumtaza ${ }^{1}$, Rahmatullah Tri Nanda Putra ${ }^{1}$, Fachrurizal Sai Kintoro ${ }^{1}$, Rezis \\ Rahayuli ${ }^{1}$, Anisa Octa Nur'aini ${ }^{1}$, Nurul Ramadhani ${ }^{1}$, Mya Dwi Rostika ${ }^{2}$, Abraham Cardenas Tristan $^{3}$ and Ratih Fitria \\ Putri $^{1 *}$
}

${ }^{1}$ Department of Environmental Geography, Faculty of Geography, Universitas Gadjah Mada, Indonesia

${ }^{2}$ Department of International Relations, Faculty of International Relations, Daita Bunka University, Japan

${ }^{3}$ Geomatics Engineering, Faculty of Engineering, Autonomous University of San Luis Potosí, México

\begin{abstract}
The gender gap that occurs in Special Capital Region of Jakarta, between men and women has an impact on aspects of employment related to labor absorption. Increasing the number of optimal employment opportunities, both in terms of productivity and efficiency, can determine the success of economic development in a region. This study was conducted to see how likely it is that women are unemployed, in relation to the employment aspect in Special Capital Region of Jakarta which is based on secondary data from BPS and analyzed with a descriptive quantitative approach. The results showed that the open unemployment rate (TPT) in Special Capital Region of Jakarta in 2019-2020 experienced a significant increase in 2020 , namely $4.86 \%$ for men and $4.5 \%$ for women. Different results are shown in the variable labor force participation rate (TPAK), which tends to experience a fluctuating trend with the participation rate of men being higher than women. In general, the COVID-19 pandemic has an impact on employment, which in turn has an impact on unemployment. During the COVID-19 pandemic, the unemployment rate was dominated by men, due to the high wages of men compared to women. In addition, women's labor force participation rates are relatively low compared to men's, causing women to have little chance of being unemployed. Female workers have higher resilience than male workers, this is due to the higher saturation of women in informal economic activities with entrepreneurship. Entrepreneurial activities tend to have more resilience than formal workers because there is no risk of termination of employment from the employer.
\end{abstract}

\section{Introduction}

The global crisis due to the COVID-19 pandemic has caused countries in the world to take policies to limit people's activities. The restrictions were made as an effort to contain the wider spread of COVID-19. This condition has an impact on various sectors. In addition to the health sector, the economic sector is one of the sectors most seriously affected by COVID-19. Based on a scenario [1], Gross Domestic Product (GDP) in 2020 in several countries experienced a decline. The COVID19 disruption to the global economy has had an impact on the employment situation, such as reduced income, reduced working hours, work from home regulations and increased unemployment.

Several studies that have raised the issue of gender equality in the impact of COVID-19 on employment have shown that women are the most affected group compared to men [2]. Gender gap research on income, expenditure, savings, and job loss by [3] in 6 countries consisting of China, Japan, South Korea, Italy, United Kingdom, and United States because of COVID-19 shows that women are $24 \%$ more likely than men to lose their jobs, and $50 \%$ more than men to experience a decline in income. In Germany, Singapore, and the United States, transitions to unemployment, reduced working hours, and transitions to working from home are more common among women than men [4].

In Indonesia, COVID-19 was first reported on March 3, 2020. Since then, COVID-19 cases have spread to 34 provinces in Indonesia. Economic activities were significantly affected by the policies taken by the government in tackling COVID-19. The policy of largescale restrictions during the COVID-19 pandemic caused severe economic losses [5]. Special Capital Region of Jakarta as the economic center in Indonesia has a high number of workers. The number of workers in Special Capital Region of Jakarta in 2019 based on the National Labor Force Survey (commonly known in Indonesia as SAKERNAS) in August 2019 reached

*Corresponding author: ratihfitria.putri@ugm.ac.id 
4,836,980 people with a higher male Employment to Population Ratio (EPR) of 76.72 percent compared to 45.01 percent for women [6]. However, with the COVID-19 pandemic, it is indicated that employment stability in DKI Jakarta in 2020 will be disrupted.

Disruption of employment stability in Special Capital Region of Jakarta due to COVID-19 has an impact on employment. The supply of labor will have a greater amount than the amount of labor needed. Employment from a gender perspective is often a consideration. This study aims to see how likely it is for women to be unemployed, related to the employment aspect. It is analyzed with a descriptive quantitative approach based on the variables of the Labor Force Participation Rate (commonly known in Indonesia as TPAK or Tingkat Partisipasi Angkatan Kerja) and the Open Unemployment Rate (commonly known in Indonesia as TPT or Tingkat Pengangguran Terbuka) in 2019 - 2020 in Special Capital Region of Jakarta.

\section{Methodology}

\subsection{Research Location}

This research is located in Special Capital Region of Jakarta with coordinates between $06^{\circ} 08^{\prime}$ latitude and $106^{\circ} 48^{\prime}$ east longitude and the area is $661.52 \mathrm{~km} 2$. Special Capital Region of Jakarta is bordered by Banten Province in the west, east and south by West Java Province, and borders the Java Sea in the north. Administratively, Special Capital Region of Jakarta is divided into 6 cities/regencies, namely the Thousand Islands, Central Jakarta, East Jakarta, West Jakarta, North Jakarta, and South Jakarta (Figure 1). Special Capital Region of Jakarta is crossed by 13 rivers which empties into Jakarta Bay with the Ciliwung River being the main river that divides the city into two parts.

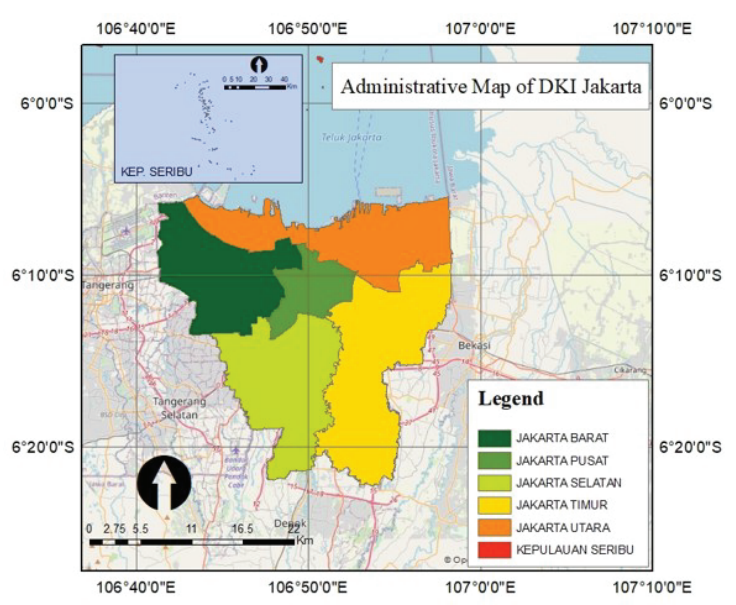

Fig. 1. Administrative of Special Capital Region of Jakarta.

Jakarta city is an area that is prone to land subsidence as a result of the excessive use of groundwater in the area [7]. One of the factors causing land subsidence is the high population density in Jakarta city. Population growth and increasing economic activity over time require an increase in the need for space. The highest population density in Jakarta is reached 15.964 people $/ \mathrm{km}^{2}$. Economic activity is one of the pull factors for the urbanization phenomenon in the region. Population growth and high activity development in Jakarta city can not be followed by the speed of development of infrastructure and other urban facilities. The need for residential land in Jakarta is increasing in line with the increasing population density. The density of settlements is a phenomenon that can be seen as one of the impacts of the high population density in Jakarta city.

The Special Capital Region of Jakarta, which is the center of the Indonesian economy, has a major contribution to national economic growth. Regional economic growth is closely related to the number of workers that can be absorbed by business fields, both in the formal and informal sectors. The COVID-19 pandemic has caused a decrease in job opportunities in Special Capital Region of Jakarta. The decrease in the number of people working is influenced by an increase in the number of workers in the informal sector while the number of workers in the formal sector has decreased. Nevertheless, the formal sector still dominates the absorption of labor in Special Capital Region of Jakarta.

\subsection{Data and Resource}

This study uses secondary data in the form of data on the number of the workforce, the population aged 15-64 years, the number of working people, and the minimum wage in Special Capital Region of Jakarta in 2019-2020. The data is sourced from the Central Statistics Agency (commonly known in Indonesia as BPS or Badan Pusat Statistik) Special Capital Region of Jakarta. Data collection techniques were carried out through literature studies from several publications, scientific articles, and journals related to labor conditions in Special Capital Region of Jakarta. The results of the employment data processing are presented in the form of tables, graphs, and maps related to the spatial distribution pattern.

\subsection{Method}

Calculations related to employment aspects in Special Capital Region of Jakarta in 2011-2019 are based on several variables that can describe employment conditions in Special Capital Region of Jakarta, such as the Labor Force Participation Rate (TPAK) and Open Unemployment Rate (TPT). TPAK is the ratio between the labor force and the total working age population. The TPAK variable is used to determine the percentage of the economically active working age population in Special Capital Region of Jakarta.

TPT is the ratio between the number of unemployed and the number of the labor force. The TPT variable is used to determine the percentage of the workforce that is included in unemployment. The results of the calculation of the four variables were then analyzed using quantitative-descriptive analysis methods. This 
method is carried out by describing data related to employment in Special Capital Region of Jakarta which has previously been calculated using several equations.

\section{Result and Discussions}

An important aspect in human life is employment where employment does not only affect the economic side, but also involves the social side. Viewed from the economic side, employment emphasizes human needs and work as an effort to fulfill the needs of daily life, while the social side emphasizes community recognition of individual abilities. The increasing number of population due to birth, death and migration factors can affect the working age population, labor force and labor market conditions in an area. The increase in the number of working age population and the labor force must be in line with the increase in the labor market and job opportunities so that it is expected to reduce unemployment and poverty levels.

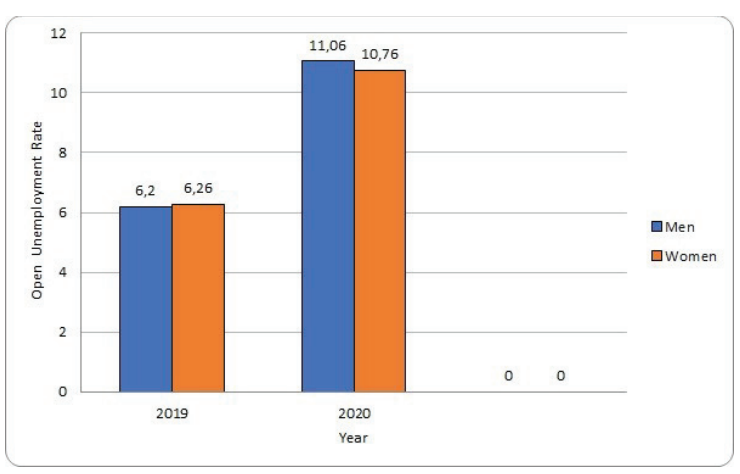

Fig. 2. Special Capital Region of Jakarta Province Open Unemployment Rate 2019 - 2020

This Open unemployment is a workforce who really does not have a job. Open unemployment can also be defined as working age population who are not working, are looking for work, preparing for a business, are looking for work and already have a job but have not started working. Unemployment can occur due to the high growth of the workforce that is not matched by the existence of jobs so that employment tends to be small. The open unemployment rate is the percentage of the number of unemployed by the total labor force.

The absorption of both male and female workers in the Special Capital Region of Jakarta Province continues to experience a fluctuating trend. The open unemployment rate (TPT) in 2020 for both men and women experienced a sharp increase. In 2020, male unemployment reached $11.06 \%$ and female unemployment reached $10.76 \%$. Both have increased compared to the previous year, where in 2019 the open unemployment rate (TPT) for men reached $6.2 \%$ and women reached $6.26 \%$. Based on this description, there has been an increase in the open unemployment rate (TPT) respectively by $4.86 \%$ for men and $4.5 \%$ for women. This illustrates that the open unemployment rate (TPT) for men has increased faster than women. The increase in open unemployment is a result of the COVID-19 pandemic. So, it can be said that in Special
Capital Region of Jakarta Province, men are classified as more vulnerable to impacts, especially related to employment during the COVID-19 pandemic compared to women. The implementation of Pembatasan Sosial Berskala Besar or PSBB (literally Large-Scale Social Restrictions) in various regions has caused economic activity to be paralyzed. In addition, the COVID-19 pandemic has also caused many employees/workers to be laid off in the formal and informal sectors. Layoffs in the informal sector reached $56.7 \%$ of the total workforce.

The vulnerability of men to the open unemployment rate during the pandemic can be caused by the higher wages of men compared to women. The average wage before the pandemic was recorded that in February 2020 the average wage for Special Capital Region of Jakarta was Rp. 4,560,084 and decreased in August 2020 to IDR $4,224.72$. The average wage has decreased because the percentage of people working full-time has decreased due to COVID-19. The average wage for both men and women is above the national average. The average wage for women, which is below the average for men, shows that men's wages are higher than women's, making them more vulnerable to open unemployment during the COVID-19 pandemic. This is in line with [8] who revealed that the minimum wage imposed in districts/cities has a significant positive effect on the unemployment rate.

A significant increase in the number of open unemployment in Special Capital Region of Jakarta occurred in August 2020 due to the COVID-19 pandemic. Many workers have stopped working from the company due to the impact of the COVID-19 pandemic or the implementation of large-scale social restrictions (PSBB). The COVID-19 pandemic has greatly impacted employment in several business fields, where business fields contribute $11.01 \%$ of employment in Special Capital Region of Jakarta [9].

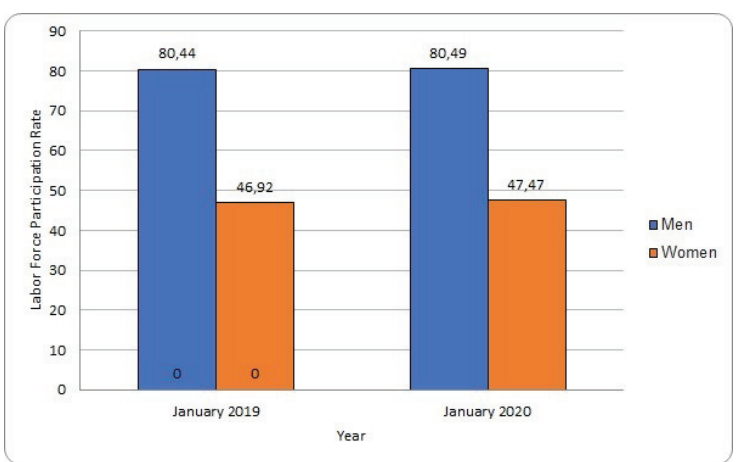

Fig. 3. Special Capital Region of Jakarta Province Labor Force Participation Rate 2019 - 2020

The labor force participation rate (TPAK) for both men and women also experienced a fluctuating trend. Based on the figure, the labor force participation rate (TPAK) of men is always higher than that of women. This can be seen in August 2019, where male TPAK reached $80.44 \%$ and female TPAK reached $46.9 \%$. In addition, it can also be seen in August 2020 where the TPAK for both men and women experienced a not too significant increase. Male TPAK in August 2020 
reached $80.49 \%$ while female TPAK reached $47.47 \%$. Both experienced an increase compared to August 2019 of $0.05 \%$ for men and $0.55 \%$ for women.

The conditions in Jakarta which show that female workers are not more affected by the pandemic than male workers are supported by the findings of [10]. According to their findings, the COVID-19 pandemic has a negative impact on male workers and young workers, which is due to the tendency of employers to terminate employment relationships with young male workers and not yet married, assuming the low socioeconomic side effects that may arise. In addition, the fact that women are more likely to work in the informal sector can also be taken into consideration, in which the sector is more resilient to economic disturbance than the formal sector. This is in accordance with the research of [11] in India, which showed that female workers in the informal sector were not negatively affected by the pandemic compared to male workers. Interestingly, they also found the fact that female workers in the formal sector were greatly affected by the pandemic.

Contrary to these findings, [12] found that on average in some Asia Pacific countries such as Bangladesh, Maldives, Nepal, and Thailand, there was a tendency that female workers were more likely to experience a negative impact on COVID-19 than male workers, both from the formal and informal sectors. This condition occurs due to the lockdown regulations and the appeal to stay at home set by the local government which is enough to force informal workers not to work amid uncertainty in living income, so it is feared that it will have a bad effect on mental health. The difference in conditions found in previous studies is supported by the statement of [13], which is based on the 2008 economic crisis. The statement [13] is that during the economic crisis, male workers in industrialized countries experienced a worse impact than women in terms of job losses. As for developing countries, the impact will depend on which economic sector is more affected. This shows that the hypothesis made in Jakarta does not necessarily apply in all regions, even though these regions have more or less the same criteria for employment conditions, so further research needs to be done.

\section{Conclusion}

Jakarta is facing a rather unique employment issue during the COVID-19 pandemic, especially in genderrelated unemployment among the workers. Women in Jakarta are experiencing less severe unemployment than men, an unseen phenomenon in other countries and regions. Most prominently, this distinctive inclination is pushed by higher resilience among female workers, due to higher saturation of women in informal economic activities with self-employment, such as small hawkers and petty service providers. This particular type of activity tends to have more resilience than formal workers due to no risk of termination from the employer. Yet, this explanation is still unfit to most cases with the similar informal dominance. Women in Bangladesh, Maldives, Nepal, and Thailand are still exposed to higher chances of being unemployed during an economic crisis, while being a state with a notoriously informal-saturated economy. Therefore, an acknowledgment is presented that this specific issue in Spesial Japital Region of Jakarta still needs further research and explanation.

\section{References}

1. W.J. McKibbin \& R. Fernando. The Global Macroeconomic Impacts of COVID-19: Seven Scenarios. SSRN Electronic Journal 1 (19) (2020)

2. N. Kabeer, S. Razavi, \& Y.V.D. Rodgers. Feminist Economic Perspectives on the COVID-19 Pandemic. Feminist Economics 27 (1-2) 1-29 (2021)

3. H.A.H. Dang, \& C.V. Nguyen. Gender inequality during the COVID-19 pandemic: Income, expenditure, savings, and job loss. World Development 140 (1) (2021)

4. M. Reichelt, K. Makovi, \& A. Sargsyan. The impact of COVID-19 on gender inequality in the labor market and gender-role attitudes. European Societies 23 (1) 228-245 (2021)

5. R.E. Caraka, Y. Lee, R. Kurniawan, R. Herliansyah, P.A. Kaban, B.I. Nasution, P.U. Gio, R.C. Chen, T. Toharudin, \& B. Pardamean. Impact of COVID-19 large scale restriction on environment and economy in Indonesia. Global Journal of Environmental Science and Management 6 (1) 65-84 (2020)

6. Special Capital Region of Jakarta Central Statistics Agency, Employment Executive Summary of Special Capital Region of Jakarta Province August 2019, Special Capital Region of Jakarta : Central Statistics Agency (2020)

7. R F Putri, S Wibirama, Sukamdi and S R Giyarsih. Population condition analysis of Jakarta land deformation area. IOP Conf. Series: Earth and Environmental Science, 148, 012007 (2018)

8. R. Pitartono, \& H. Banatul. Analysis of the Unemployment Rate in Central Java 1997 - 2010. Dipenegoro Journal of Economics 1 (1) 1-10 (2012)

9. BPS, Impact of COVID-19, Special Capital Region of Jakarta Unemployment Reaches Double Digits, Official News Statistics, BPS Special Capital Region of Jakarta Province (2020)

10. Z. Yu, Y. Xiao, Y. Li, Emerg. Mark. Financ. Trade, 56, 2390 (2020)

11. S. Desai, N. Deshmukh, S. Pramanik, Fem. Com. 27, 152 (2021)

12. P.A. Seck, J.O. Encarnacion, C. Tinonin, S. Duerto-Valero, Fem. Com. 27, 123 (2021)

13. United Nations Women, The Global Economic Crisis and Gender Equality, New York: UN Women (2014) 